\title{
USING THE BROKEN NEEDLE TECHNIQUE FOR PERIPHERAL VENOUS PUNCTURE IN ASSISTANCE TO PREMATURE NEWBORN
}

\author{
Utilização da técnica broken needle para punção venosa periférica na \\ assistência a recém-nascidos prematuros

\section{Utilización de la tecnica broken needle para punto venosa periférica en la asistencia a reciénnos prematuros}

Letícia Morais Pagano ${ }^{1}$, Denis da Silva Moreira², Zélia Marilda Rodrigues Resck ${ }^{3}$

\section{How to cite this article:}

Pagano LM, Moreira DS, Resck ZM. Using the broken needle technique for peripheral venous puncture in assistance to premature newborn. Rev Fun Care Online. 2020 jan/dez; 12:6-11. DOI: http://dx.doi.org/ 10.9789/2175-5361.rpcfo.v12.6595.

\begin{abstract}
Objective: to understand the use of the broken needle technique peripheral venous puncture in the professional practice of assistance to preterm infants. Method: qualitative study conducted through interviews with neonatal care professionals submitted to Content Analysis to Bardin. Results: the following categories were identified: Professional perceptions regarding the benefits of the broken needle technique for the neonate; Learning and professional experience of broken needle technique. Conclusion: the transfer of knowledge from one professional to another favored the incorporation of the technique in the institution. The team is concerned with performing techniques that are less aggressive to the newborn and therefore perform the broken needle because they believe it is more advantageous and beneficial and has no adverse effects on the neonate. The professionals decide which technique to use taking into account the anatomical and clinical characteristics of the neonate, their ability and safety in the execution.
\end{abstract}

Descriptors: Nursing; Neonatal nursing; Blood specimen Collection; Punctures; Infant, premature.

\section{RESUMO}

Objetivo: compreender a utilização da técnica broken needle de punção venosa periférica na prática profissional de assistência a neonatos prematuros. Método: estudo qualitativo realizado por meio de entrevista a profissionais da assistência neonatal submetida à Análise de Conteúdo segundo Bardin. Resultados: foram identificadas as categorias: Percepções dos profissionais quanto aos benefícios da técnica broken needle para o neonato; e Aprendizado e vivência profissional da técnica broken needle. Conclusão: a transferência do conhecimento de um profissional ao outro favoreceu a incorporação da técnica na instituição. A equipe se preocupa em realizar técnicas que sejam menos agressivas ao neonato e, portanto realizam a broken needle porque acreditam que seja mais vantajosa e benéfica e não

1 Nursing Graduate by the Universidade José do Rosário Vellano (UNIFENAS), MSc in Nursing by the UNIFAL, Postgraduate student in Health Educators Training by the Universidade Federal de Minas Gerais (UFMG), Nurse.

2 Nursing Graduate by the UNIFAL, MSc in Biological Sciences/Pharmacology by the UNIFAL, PhD in Nursing by the Escola de Enfermagem de Ribeirão Preto at Universidade de São Paulo (EERP/USP), Postdoc by the EERP/USP, Professor at UNIFAL.

3 Nursing Graduate by the Pontifícia Universidade Católica de Campinas (PUC-Campinas), MSc in Education by the UNIFENAS, PhD in Nursing by the EERP/USP, Postdoc by the EERP/USP, Professor at UNIFAL. 
tenha efeitos adversos ao neonato. Os profissionais decidem qual técnica utilizar levando em consideração as características anatômicas e clínicas do neonato, a sua habilidade e segurança na execução.

Descritores: Enfermagem; Enfermagem neonatal; Coleta de amostras sanguíneas; Punções; Recém-nascido prematuro.

\section{RESUMÉN}

Objetivo: comprender el uso de la técnica broken needle de punción venosa periférica en la práctica profesional de asistencia a neonatos prematuros. Método: estudio cualitativo realizado por medio de entrevista a profesionales de la asistencia neonatal sometida al Análisis de Contenido según Bardin. Resultados: se identificaron las categorías: Percepciones de los profesionales en cuanto a los beneficios de la técnica broken needle para el neonato; Aprendizaje y vivencia profesional de la técnica broken needle. Conclusión: la transferencia del conocimiento de un profesional al otro favoreció la incorporación de la técnica en la institución. El equipo se preocupa de realizar técnicas que sean menos agresivas al neonato $y$, por lo tanto, realizan la técnica porque creen que es más ventajosa y benéfica y no tiene efectos adversos al neonato. Los profesionales deciden qué técnica utilizar teniendo en cuenta las características anatómicas y clínicas del neonato, su habilidad y seguridad en la ejecución.

Descriptores: Enfermería; Enfermería neonatal; Recolección de muestras de sangre; Punciones; Recien nacido prematuro.

\section{INTRODUCTION}

Prematurity is still one of the main causes of neonatal morbidity and mortality. Data from the World Health Organization (WHO) point to Brazil as the tenth country with the largest number of preterm births, preceded by countries such as India, China, Nigeria and the United States of America. ${ }^{1}$ Preterm birth has been conceptualized as the birth of a neonate alive below 37 weeks of gestation and can be divided into subcategories related to gestational age as follows: extreme premature (below 28 weeks), very preterm ( 28 to 32 weeks), and moderate to late preterm (32 to less than 37 weeks). ${ }^{1}$

Technological advances have contributed to the increase of the survival of preterm Newborns (NB), also increasing the procedures performed. Peripheral Venous Puncture (PVP) is among the several procedures performed in the Neonatal Intensive Care Unit (NICU), being considered a routine practice by the health team. It can be performed for therapeutic and diagnostic purposes such as the collection of exams, also being cited as one of the most complex and risky practices performed by nursing in the neonate. Studies show that venipuncture represents $85 \%$ of the activities of the nursing team, being also the most painful., ${ }^{2,3}$

The PVP is described as an invasive and aseptic technique, common to any patient, regardless of age, and consists of the introduction of a device in the venous network, whether or not it is permanent or not, which must be chosen, taking into account the purpose of the procedure and the clinical conditions of the patient. It may be aimed at infusing solutions or collecting blood samples for laboratory diagnosis. It is of medical competence and of the nursing team, and knowing the complications and constant updates regarding the safe practice of PVP should be a team priority. ${ }^{4}$
Due to the physiological characteristics of the neonatal period, such as immaturity, hemodynamic variation to manipulation, risk of infection and high sensitivity to pain, some complications related to venipuncture are more common in newborns: pain, bruising, perivascular tissue necrosis, thrombophlebitis, phlebitis, cellulitis of the underlying tissue, infection, sepsis, infiltration, and extravasations. Despite this, PVP is indispensable in care, being the source of administration of medication, parenteral nutrition, blood products and collection of material for examinations. ${ }^{3,5,6}$

It has been recognized for some time that medical devices used in adults have been adapted for use in infants and toddlers. Although contrary to the manufacturer's guidelines, this practice is common in areas where there is no specific and easily accessible device for pediatric care. Among these practices is the broken needle technique. Such a technique consists of opening the sterile needle carton, holding the needle wrapped in the protective sleeve in one hand, and pulling the needle barrel up and down with one hand. In this movement, the gun is fragmented from the needle and it remains sterile inside the plastic protection until the moment of the puncture. Only the needle stem is inserted into the vein and the drops that exit at the opposite end are collected directly into the tube to be sent to the laboratory (Figure 1). This technique has been considered useful by professionals of several institutions for facilitating the collection of blood samples, although some studies consider the risk of adverse events. ${ }^{4}$ However, it has not yet been proven whether one device is more efficient than another for the collection of newborn blood, or whether it is possible that one technique is less painful than another. ${ }^{7}$

Figure 1 - Blood sample collection and dripping through the broken needle technique. ${ }^{8}$

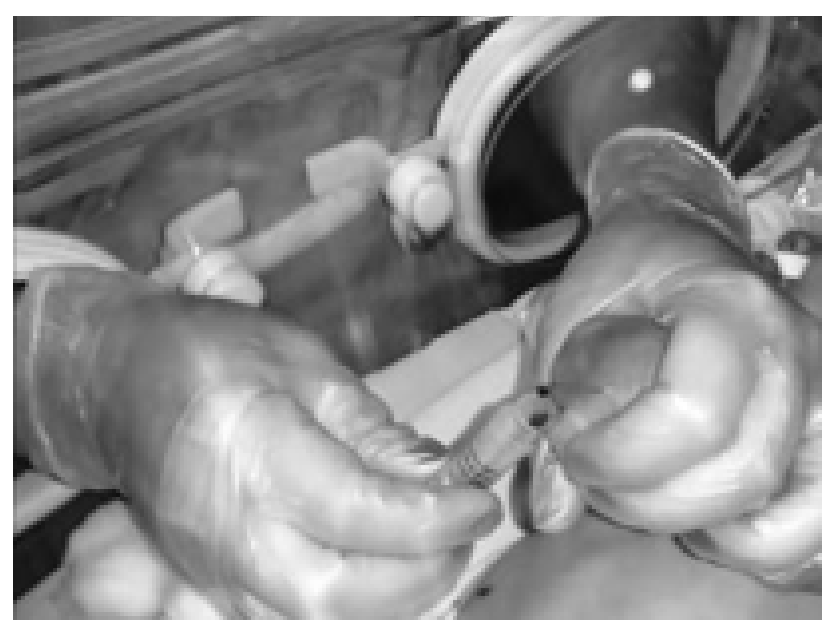

The venipuncture is performed by professionals with different levels of training and qualification, which can cause variability techniques, and even as a routine procedure neonatal inherent to the realization of this procedure is not always discussed. The PVP must undergo constant assessments and improvements since the assistance portrays the professional empiricism in adapting techniques they believe to be appropriate for certain procedures. It emphasizes 
the importance of reviewing care techniques, adapting the new construction of knowledge and technologies, build new knowledge, develop new research and potential of the human being, and stimulate critical reflection focused on seeking its own nursing theory. ${ }^{9}$

This research started from the practical observation of the work of the support staff of the NICU, which currently uses this unconventional technique of blood collection and the study is justified by the need for answers about its use in relation to how it has been their use by assistance. There is a gap in studies that propose the evaluation and improvement of the practice of neonatal peripheral venipuncture. The aim is to understand the use of the broken needle technique of peripheral venous puncture in the professional practice of care for preterm newborns.

\section{METHODS}

This is a qualitative study in which semi-structured interviews were conducted and the data obtained were analyzed according to the Bardin's Content Analysis, which offers a set of communication analysis techniques. ${ }^{10}$

The population was constituted by members of the health team of the NICU who perform the broken needle technique. The care of the newborns is carried out by a team of four nurses, 22 nurse technicians, and four physicians, distributed in the morning, afternoon and night shifts. Nevertheless, only nurses and a physician perform this technique, due to the Institution's Standard Operating Procedure, which makes the execution of the procedure private to the nurse. The medical professional that performs the technique is the same one who implanted the same in the institution under study. The professionals were elected according to the criteria: professionals of both genders who work in the NICU and professionals who perform blood collection through the broken needle technique in the peripheral venous puncture. Exclusion criteria were: professionals on vacation, maternity leave or retired due to health reasons at the time of data collection. No professionals were excluded from the study and therefore five professionals, four nurses, and one doctor participated.

For the data collection, an instrument was elaborated, containing: professional characterization (professional category of the interviewee, training time and professional experience, if he/she has a specialization in neonatology and contact time with the broken needle technique) and the guiding and complementary questions of the research: "Discuss your experience of using broken needle technique in peripheral blood collection in the neonate", "what do you observe when using the broken needle technique in peripheral blood collection in the neonate?", and a space for the interviewee could contribute with additional or spontaneous comments desired by him.

The professionals were approached by the researcher, who clarified about the study to be performed and verified the interest in participating in the study. After that, the day and time for the interview were scheduled, so that it did not interfere with the routine of neonatal care.
All interviews were conducted individually in private rooms available at the NICU. At the time of the interview, the researcher reinforced the objectives of the study, the maintenance of anonymity and the freedom of the subject to interrupt the interview any time she wanted.

Data were recorded to record aiming to have the speeches saved in full, which were then transcribed by the researcher. Participants' speeches were identified by letter and number, as example "P1", corresponding the letter "P" to "professional" and the number of the speech, which was assigned randomly.

Data collection was only carried out after the approval of the Research Ethics Committee from the Universidade Federal de Alfenas - UNIFAL/MG, and according to the Resolution No. 466/12, then obtaining a favorable Legal Opinion No. 1.980.279. The professional was asked to sign the Free and Informed Consent Term and they were given a course.

The interviews were submitted to the Bardin content analysis method, which uses systematic and objective procedures to describe the content of messages in three phases: pre-analysis; exploitation of the material; Treatment of results, inference, and interpretation. ${ }^{10}$

The pre-analysis phase was constituted, in the organization itself, at which time the material was organized, the documents that were analyzed were chosen, the hypotheses and guiding questions were formulated. The collected transcribed interviews constituted the corpus of the research. In this phase the floating reading is used, in which the researcher comes in contact with excerpts of the speech and connects with the first impressions of the explored text.

The next stage was the material exploration phase, in which the raw data was coded. During the codification the Registration Units (RUs) were chosen, the counting rules were selected and the categories were elected as well. Each RU is a unit of meaning to code, which can be the theme, word or phrase. The importance of a RU increases with its frequency of appearance. In this study of thematic categories, the criterion of categorization was semantic and the codification was made by cuts. The topic was defined as the Registration Unit and, as a unit of context, the phrase, which in turn assists in the comprehension of the registration unit and corresponds to the follow-up of the message whose dimensions are larger than those of the registration unit. ${ }^{10}$

The last step was carried out with the treatment of the obtained results and interpretation. In discovering a common theme in the data, it was necessary to compare statements and actions among themselves to see if there is something that would unify them. The definition of the themes allowed the selection of the cuts of the messages that were organized into categories and subcategories. The data obtained by the content analysis made possible the proposition of inferences and interpretations in relation to the objectives predicted in the research, dialoguing with authors about the themes found.

\section{RESULTS AND DISCUSSION}

Considering the professionals interviewed, all were female, four nurses (80\%) and one doctor (20\%), being the 
only professionals who perform the broken needle technique in the institution.

All professionals have a specialization in neonatology and have an average experience of 10.7 years in this sector. The average time of knowledge and experience with the technique under study is 9.9 years.

After the transcription of the recorded speech, the data were analyzed and the RU that contained meaning related to the object of the study were located. The RUs were grouped into thematic categories and thus two categories and four subcategories were identified that converged to the proposed goals: Category 1 "Professional's perceptions regarding the benefits of the broken needle technique for the neonate"; Category 2 "Learning process and professional experience related to the broken needle technique".

\section{Category 1: Professional's perceptions regarding the benefits of the broken needle technique for the neonate}

In this category, a subcategory has been identified: "Benefits and advantages for the neonate". The registry units that built it are the following: benefits and advantages for the $\mathrm{NB}$, pain and behavioral changes.

When describing their experiences with the use of the broken needle technique, the participants reported that the technique seems to be less aggressive to the neonate, since it does not require the use of materials that may represent an aggression and discomfort such as the use of the club. It is observed by the speeches that also consider it less aggressive for being able to complete the collection generally in the first attempt:

\section{I think there is less aggression. (P1)}

This technique of breaking the cannon is much better even by the delicacy of the baby's handling [...] Getting it right at first, you do not have to sting the baby several times. (P2)

I see the baby more comfortable [...] And this technique you do not even use the tourniquet. (P5)

Although they recognized that venipuncture is a painful procedure, professionals report based on their experience that the neonate seems to feel less pain when subjected to this puncture technique. The professionals do not use in their clinical practice the evaluation of neonatal pain through existing instruments, but they perceive less expressive signs of pain, according to the following statements:

The painful feeling seems to be less when we fragment the needle. (P1)

Normally, we observe that the painful sensitivity in newborns is not so much, some babies do not even cry. Thus, I think it's less painful for the baby, we see it this way: the facial signs are much more expressionless the signs of pain. (P5)

\section{Category 2: Learning process and professional experience related to the broken needle technique}

In this category, three subcategories were identified, the first being: "Standard Operating Procedure (SOP) of the broken needle technique". The registry units that built it are the following: technique and procedure and institutional standards. It is observed in the professionals' speech that the existence of an institutional protocol organizes and standardizes the assistance, leaving the professional executors more secure:

It is protocol in the ICU to be collected only by the nurse. (P1)

You perform asepsis, sometimes we do not even use tourniquet, just with our hands we are going to give the massaged one in the place and already it is able to realize the collection [...] You pump with the own hand, you hold there of a certain form and pumps [...] We use it for everything here, for all sorts of peripheral blood collection. (P5)

The second subcategory is "Teaching and learning process in professional practice", formed by the URs: learning, replication, and continuity.

The experience reported by the professionals interviewed shows the importance of the process of education and teaching in service and constant updating of professionals, considering that professionals generally exchange information and knowledge among themselves, mainly occurring passing information from older professionals to new ones:

When we came in here ten years ago... they already had two nurses and we learned from them that technique, which they learned from another nurse like that. And we continue... we did continue. That's what I told you, there (in the institution where you did the specialization) in Belo Horizonte city also everyone was picking up that way at the time we did, and even today. (P3)

I learned here in the neonatal ICU from my colleagues, one was passing to the other. Then, we try to teach other people, to pass on to them [...] After I've learned it, I never give up. (P5)

The Registration Units: anatomical characteristics of the neonate, comparison with other techniques and the advantages for the professional form the third subcategory, called "determining factors of picking the technique".

During the interviews, it was observed that certain phrases showed the reason for the choice of this technique by the professionals, who went beyond the fulfillment of the institutional SOP. Among these factors are the venous 
anatomy of the newborn, the small size of the limbs and the caliber of the vessels:

The venous access is more difficult in the baby, that the caliber of the vein is thinner [...] Even if it is a vein that has no segment, we can do it. (P1)

The very small hand and the vessels are also very thin, so it eases a lot during the puncture. (P2)

In the practical experience, the professionals consider the broken needle technique easy and less delayed to facilitate greater blood flow, as evidenced by the following statements:

It makes it much easier [...] So, when you break up the needle, it's easier for you to have a greater flow of blood in less time. The time is shorter because you can because the broken needle is smaller; the flow goes faster, so it takes less time. (P1)

I realized that if I broke the needle's bevel (blood) would come more easily. I note that the collection gets faster, [...] and the direct dripping inside the bottle ends up speeding up this whole process. I handle less with my hands. (P4)

The professionals compared the broken needle technique with other venipuncture techniques and the fact that it is feasible to collect a sample for several tests, to have a venous return apparently faster and not to interfere in the results of the blood tests, favors the choice of this technique, according to the following statements:

The cannon, in addition to weighing the needle, runs the risk of losing access there at the time of puncture, it has to fill with blood first and then start to drip. This often results in blood clotting in the cannon. Sometimes it weighs and loses the vein, loses the puncture that we made and the venous return is very slow. So, even filling the cannon makes collecting difficult. (P2)

Actually, I saw the collection of three forms: with the scalp, which I found more difficult because for the blood to come in the syringe in which you were collecting had a bigger space to fill, then we realized that we had to milk more and the sometimes it made more bruising. And the collection with the cannon that was very long the needle, as it had no blood pressure, came more slowly. The only difference could be in gasometry, but that the venous one already has a difference in $\mathrm{PaO}_{2}$ (arterial blood gas). As you use venous blood gases to see $\mathrm{pH}$ and bicarbonate base excess, this does not interfere with ambient air. And blood culture we do not do this way, because we are not able to obtain the needed purity. (P4)
Participating professionals have considered important that blood collection was rapid and performed with the least number of punctures. They associate the advantage of the broken needle technique with the number of punctures. The multiple punctures also represent suffering for the team that performs them. A study conducted in Rio de Janeiro ${ }^{11}$ also found a similar result in the professionals' speech, who reported that to reduce pain during the procedure it was necessary to puncture once or to do so in a way that "would end soon". There are studies that show that there is pain reduction in neonates when the smallest number of punctures is performed. ${ }^{3}$

In the professionals' speech there is the perception that the collection with the broken needle technique is less painful for the neonate since they affirm that the NB generally does not cry and the facial signs of pain are less expressive during the collection. This perception may be related to the profile of the professionals because they have a specialization in neonatology and already have a valuable time of professional experience. A similar situation was also observed in a randomized clinical study in which skilled nursing professionals scored neonatal pain with higher values on an assessment scale than generalist nurses. ${ }^{12}$

The study cited above also reinforces the importance of advanced health education and training, since the knowledge of the health team interferes directly with neonatal care. ${ }^{12}$ The importance of team training was also evidenced in this present study, considering that professionals value the information passed from one member to another of the team. In another study on venipuncture in the NICU, ${ }^{8}$ the findings were also in agreement with those of the current study, since the professionals stated that they had learned the technique of venipuncture with co-workers. In-service education can result in the implementation of new techniques and incorporation into the organizational culture, with a direct impact on patient care.

According to professionals, the broken needle technique seems to be appropriate for a collection of samples for different tests, with the exception of arterial blood gases. The professionals decide on the technique to be used for peripheral blood collection taking into account the anatomical and clinical characteristics of the newborn and the type of examination to which blood samples will be submitted. The characteristics: immature skin, the fragility of the venous network, the risk of infection, greater hemodynamic lability and less amount of subcutaneous tissue have been taken into account by the team, according to what the literature suggests. Our findings are also in agreement with other studies that have evaluated the main location of peripheral venous accesses in the pediatric and neonatal population, which show that the dorsal arch of the hand or metacarpal veins is first choice. ${ }^{6}$

There is also concern about following the institutional protocol for collection, valuing the planning, organization, and rationalization of procedures. The standardization of procedures is a managerial tool that assists nurses in decision 
making, allows all workers to provide patient care according to the institution's technical and scientific principles, corrects the distortions acquired in practice and has an organizational characteristic that will result in the improvement of processes and results. ${ }^{13}$ Hence, the existence of a protocol in the institution ensures that the procedure is performed in a standardized way, avoiding subjectivity in decisions.

When we decided to study the broken needle technique, we then faced the great shortage of studies that underlie the technique, its historical description, as well as the adaptation of other puncture techniques by the nursing team. Despite the report of professionals from other institutions that carry out the technique, it continues to be executed without major scientific grounds, it is suggested to carry out other studies, even with a national scale, with a larger number of participants.

\section{CONCLUSIONS}

This study allowed the understanding of the use of the broken needle technique by professionals in the care practice. It was concluded that the transfer of knowledge from one professional to another favored the incorporation of the technique in the institution. The team is concerned with performing techniques that are less aggressive to the neonate and therefore perform the broken needle technique because they believe it is more advantageous and beneficial and has no adverse effects on the neonate. The professionals get to decide the technique to be used taking into account the neonate's anatomical and clinical characteristics, how easy it is, and also their ability and safety in the execution as well.

\section{REFERENCES}

1. Organização Mundial de Saúde - OMS. Nascimentos prematuros nota descritiva. 2016 Nov. Disponível em: http://www.who.int/ mediacentre/factsheets/fs363/es/.

2. Nóbrega FS, Sakai L, Krebs VLJ. Procedimentos dolorosos e medidas de alívio em unidades de terapia intensiva neonatal. Rev med (São Paulo). 2007 out-dez;86(4):201-6.

3. Rodrigues EC, Cunha SR, Gomes R. "Perdeu a veia": significados da prática da terapia intravenosa na unidade de terapia intensiva neonatal. Cienc saúde coletiva (online). 2012;17(4):989-99.

4. Marteleto CA, Ferreira SCM, Leitão RER, Valente GSC. A supervisão no processo de trabalho do enfermeiro: um olhar sobre a punção venosa periférica. Rev pesq cuid fundam (Online). 2010;2(3):1095 104. Disponível em: http://www.seer.unirio.br/index.php/ cuidadofundamental/article/view/577.

5. Ministério da Saúde (BR), Secretaria de Atenção à Saúde, Departamento de Ações programáticas e estratégicas. Atenção à saúde do recém-nascido: guia para os profissionais de saúde. Brasília: Ministério da Saúde, 2011.

6. Diehl L, Marin AH. Adoecimento mental em docentes brasileiros: Cardoso JMRM, Rodrigues EC, Rodrigues BMRD, Pacheco STA, Faria JCO. Rev RENE. 2011;12(2).

7. Hunt J, Donaldson N, Tizzard S, Rennie J. Three venepuncture techniques in babies: a comparative study. King's College Hospital. 2001:1-23.

8. Oliveira ECV. A prática da punção venosa na coleta de sangue em recém-nascidos em um hospital público universitário [dissertação]. Uberaba: Universidade Federal do Triângulo Mineiro;2013.

9. Santos LM, Santana DM, Gomes TR, Santana RCB. Analysis of peripheral venous catheters fixation in premature newborns. Rev enferm UFPE on line. 2012;5(3).

10. Bardin L.Análise de conteúdo. São Paulo: Edições 70; 2009.
11. Fonseca EFR, Christoffel MM, Rosa PAN. Nursing actions in venipuncture: minimizing the pain of the newborn. Rev pesq cuid fundam (Online).2010 abr-jun;2(2):947-57. Disponível em: http://www. seer.unirio.br/index.php/cuidadofundamental/article/view/578.

12. Sorrentino G, Fumagalli M, Milani S, Cortinovis I, Zorz A, Cavallaro $\mathrm{G}$, et al. The impact of automatic devices for capillary blood collection on efficiency and pain response in newborns: a randomized controlled trial. Int j nurs stud. 2017;72:24-9.

13. Almeida ML, Segui MLH, Maftum MA, Labronici LM, Peres AM. Instrumentos gerenciais utilizados na tomada de decisão do enfermeiro no contexto hospitalar. Texto \& contexto enferm. 2011;20:131-7. 